\title{
EKSTRAKSI MINYAK ATSIRI BUNGA MELATI: PENGARUH RASIO MASSA BUNGA MELATI DENGAN VOLUME PELARUT N-HEKSANA, WAKTU EKSTRAKSI, DAN TEMPERATUR EKSTRAKSI
}

\section{EXTRACTION OF JASMINE ESSENTIAL OIL: THE EFFECT OF RATIO BETWEEN JASMINE FLOWER TO N-HEXANE AS SOLVENT (M/V), TIME, AND TEMPERATURE}

\author{
Michael Dillo Rizki Ginting*, Febrina Iskandar, Iriany, Okta Bani \\ Departemen Teknik Kimia, Fakultas Teknik, Universitas Sumatera Utara \\ Jalan Almamater Kampus USU Medan, 20155, Indonesia \\ *Email : michaeldillo@yahoo.com
}

\begin{abstract}
Abstrak
Bunga melati (Jasminum Sambac) mengandung senyawa minyak atsiri. Minyak atsiri bunga melati merupakan minyak atsiri berkualitas tinggi. Minyak atsiri atau sering juga disebut essential oils/volatile oils memiliki aroma mirip dengan tanaman asalnya. Minyak atsiri bunga melati dicari karena karateristiknya yang menenangkan dan anti-depresan. Pada penelitian ini, diamati pengaruh temperatur, waktu dan rasio berat bunga melati dan volume pelarut terhadap ekstraksi minyak atsiri dari bunga melati dengan pelarut n-heksana. Ekstraksi dilakukan pada temperatur $30^{\circ} \mathrm{C}, 35^{\circ} \mathrm{C}$, dan $40^{\circ} \mathrm{C}$ selama 2 jam, 3 jam, 4 jam, dan 5 jam. Perbandingan massa bunga melati terhadap pelarut n-heksana yang digunakan adalah 1:3; 1:4; dan 1:5. Analisa yang dilakukan adalah analisis rendemen absolut, analisis komposisi dengan menggunakan GC-MS, dan analisis kualitas minyak atsiri bunga melati dengan metode SNI 06-2385-2006 yang meliputi uji warna, analisis indeks bias, analisis bilangan asam, dan analisis bilangan ester. Penelitian ini menunjukkan bahwa peningkatan waktu ekstraksi, suhu ekstraksi, dan volume pelarut yang digunakan dapat meningkatkan rendemen absolut minyak atsiri bunga melati yang diperoleh. Hasil penelitian terbaik yang diperoleh pada penelitian ini memiliki rendemen absolut minyak atsiri sebesar $11,69 \%$, mengandung benzil asetat sebesar $47,14 \%$, berwarna kuning, memiliki indeks bias sebesar 1,478, bilangan asam sebesar 20,92 $\mathrm{mg} \mathrm{KOH}$ / gram minyak melati, dan bilangan ester sebesar 150,27 mg KOH/ gram minyak melati.
\end{abstract}

Kata kunci: Bunga melati, ekstraksi, n-hexane, minyak atsiri, bunga melati

\begin{abstract}
Jasmine flower (Jasminum sambac) contains essential oil compounds. Jasmine flower essential oil is a high-quality essential oil. Essential oils are volatile oils that have aroma similar to the original plant. Jasmine flower essential oil is sought due to its calming and anti-depression nature. In this study, the effect of extraction temperature, extraction time and solvent to jasmine flower ratio on jasmine oil was studied. The extraction was carried out at $30^{\circ} \mathrm{C}, 35^{\circ} \mathrm{C}$, and $40^{\circ} \mathrm{C}$ for 2 hours, 3 hours, 4 hours, and 5 hours by using $n$-hexane. The ratio of jasmine flower to $n$-hexanes were $1: 3 ; 1: 4$; and $1: 5(\mathrm{w} / \mathrm{v})$. Resulting jasmine oil was analyzed by GC-MS, and its quality was assessed according to SNI 06-23852006 which include colour test, refractive index analysis, acid number analysis, and ester number analysis. This experiment showed that increasing of extraction time, extraction temperature, and volume of solvent lead to increase of absolute yield of jasmine essential oil. The highest jasmine oil yield obtained at $11.69 \%$. The jasmine oil contained was $47.14 \%$ benzyl acetate and had yellow color. Its refractive index, acid number, and ester number were 1.478, $20.92 \mathrm{mg} \mathrm{KOH} /$ gram jasmine essential oil, and $150.27 \mathrm{mg} \mathrm{KOH} /$ gram jasmine essential oil respectively.
\end{abstract}

Keywords: Jasmine flower, extraction, $n$-hexane, jasmine essential oil 


\section{Pendahuluan}

Minyak atsiri adalah salah satu komoditi yang memiliki potensi besar di Indonesia. Minyak atsiri adalah ekstrak alami dari jenis tumbuhan tertentu, baik berasal dari daun, bunga, kayu, biji-bijian bahkan putik bunga. Meskipun banyak jenis minyak atsiri yang bisa diproduksi di Indonesia, baru sebagian kecil jenis minyak atsiri yang telah diusahakan di Indonesia. Indonesia memiliki kepentingan terhadap minyak atsiri saat ini, karena Indonesia menjadi salah satu produsen minyak atsiri terbesar di dunia untuk beberapa komoditi.

Ekspor minyak atsiri Indonesia ke dunia bersifat fluktuatif setiap tahunnya. Berdasarkan data International Trade Centre (ITC), nilai ekspor minyak atsiri Indonesia pada 2009 sebesar USD 91 juta, bahkan nilainya melonjak hingga USD 161 juta pada tahun 2011. Meskipun pada 2013, nilai ekspor minyak atsiri Indonesia ke pasar dunia turun ke angka USD 123 juta dan menempatkan Indonesia di peringkat ke-9 eksportir terbesar di Dunia.

Dengan semakin berkembangnya industri yang memanfaatkan minyak atsiri, termasuk minyak melati, maka ekstraksi tanaman melati membuka peluang investasi karena kegunaannya yang beragam dan juga memiliki nilai ekonomi yang cukup tinggi [7].

Penelitian ini menggunakan metode ekstraksi pelarut menguap dengan menggunakan pelarut n-heksana. Dipilihnya metode pelarut menguap sebagai metode dalam proses ekstraksi pada penelitian ini ialah dikarenakan oleh sifat minyak atsiri bunga melati yang tidak tahan terhadap suhu yang tinggi. Selain itu hal yang menjadi pertimbangan dari pemilihan metode ini adalah penggunaan waktu yang cukup singkat jika dibandingkan dengan metode ekstraksi pada suhu rendah lainnya. Dipilihnya n-heksana sebagai pelarut pada ekstraksi minyak atsiri dari bunga melati ini dikarenakan oleh sifatnya yang merupakan pelarut non-polar sehingga cocok untuk minyak atsiri yang bersifat non polar dan juga mempunyai titik didih yang cukup rendah, yaitu sebesar $68^{\circ} \mathrm{C}$.

\section{Teori}

Tanaman melati terdapat hampir disetiap daerah di Indonesia. Adapun jenis melati yang ditemukan antara lain Jasminum sambac (melati putih), Jasminum multiflorum (star jasmine) dan Jasminum officinale (melati gambir). Melati merupakan salah satu komoditas bernilai ekonomi tinggi, kegunaannya tidak hanya sebagai tanaman hias pot dan taman, tetapi juga sebagai bahan baku industri parfum maupun kosmetik, dan juga sebagai bahan pengharum teh [16].

Berikut merupakan klasifikasi dari tanaman melati.

$\begin{array}{ll}\text { Kingdom } & \text { : Plantae } \\ \text { Divisi } & \text { : Magnoliophyta } \\ \text { Kelas } & \text { : Magnoliopsida } \\ \text { Ordo } & \text { : Lamiales } \\ \text { Famili } & \text { : Oleaceae } \\ \text { Genus } & \text { : Jasminum }\end{array}$

Minyak atsiri bunga melati memiliki nilai ekonomi yang tinggi terutama dalam penggunaanya sebagai aromaterapi. Harga minyak atsiri bunga melati yang beredar dipasaran berkisar $\mathrm{Rp} 100.000,00 \quad-\mathrm{Rp}$ 140.000,00 per $7 \mathrm{ml}$ minyak atsiri [8].

Komponen terbesar yang menyusun minyak melati adalah benzyl acetate, linalil asetat, cis jasmone, Z-jasmone, dan linalool. Senyawa dari minyak atsiri bunga melati berupa benzil asetat dan linalool merupakan pemberi aroma yang kuat pada minyak bunga melati. Komponen ester tertinggi yang terdapat pada bunga melati adalah benzil asetat [16]. Berikut merupakan spesifikasi dari minyak atsiri bunga melati $[3,9,15]$.

$\begin{array}{ll}\text { Warna } & : \text { Kuning } \\ \text { Wujud } & \text { : Cairan kental } \\ \text { Aroma } & : \text { Berbau bunga melati } \\ \text { Indeks bias } & : 1,478-1,492 \\ \text { Bilangan asam } & : 18,83-29,85 \mathrm{mg} \mathrm{KOH} \mathrm{/} \mathrm{g} \\ & \text { minyak } \\ \text { Bilangan ester } & : \begin{array}{l}143,408-186,556 \mathrm{mg} \mathrm{KOH} / \\ \mathrm{g} \text { minyak }\end{array}\end{array}$

Pelarut yang dapat digunakan untuk mengekstraksi minyak atsiri antara lain alkohol, heksana, benzena, toluena, kloroform, petroleum eter, dietil eter, dan juga etil asetat. Komponen minyak atsiri bersifat non-polar, sehingga pelarut yang digunakan untuk mengekstrak komponen minyak atsiri dipilih yang juga bersifat non-polar. Selain itu, titik didih pelarut juga dapat mempengaruhi rendemen yang dihasilkan, karena pada proses ekstraksi, ekstrak dan pelarut harus dipisahkan dengan metode penguapan, sehingga titik didih kedua bahan tidak boleh terlalu dekat dan jika ditinjau dari segi ekonomi, akan lebih menguntungkan jika titik didih kedua bahan juga tidak terlalu jauh [17].

n-Heksana merupakan pelarut non-polar yang dapat melarutkan senyawa-senyawa nonpolar, Dalam keadaan standar senyawa ini merupakan cairan tak berwarna yang tidak larut dalam air [15].

Berikut merupakan karateristik n-heksana [15] : Nama lain : caproyl hydride, hexyl hydride

Berat molekul $\quad: 86,17 \mathrm{~kg} / \mathrm{mol}$ 
Warna

Titik lebur

: tidak berwarna

Titik didih

: $94,3{ }^{\circ} \mathrm{C}$

Densitas

: $69(\mathrm{P}=1 \mathrm{~atm})$

: $0,0095 \mathrm{~g} / \mathrm{l}$ pada $20^{\circ} \mathrm{C}$

Salah satu metode yang dapat digunakan untuk mengekstraksi bunga melati adalah metode ekstraksi pelarut menguap. Metode ekstraksi pelarut menguap merupakan suatu metode ekstraksi yang menggunakan pelarut mudah menguap. Pelarut yang biasa digunakan dalam metode ini adalah pelarut non-polar atau semi polar yang memiliki titik didih rendah seperti n-heksana, etanol, klorofom, pertoleum eter, dan dietil eter. Proses ekstraksi dengan pelarut, dipengaruhi oleh sifat pelarut yang akan dipakai dan pemilihan pelarut ditentukan oleh kelarutan bahan volatil dan kemudahan pemisahan pelarut. Suatu senyawa akan mudah larut dalam pelarut yang mempunyai polaritas yang sama atau mirip [6].

\section{Metodologi Penelitian \\ Pengumpulan Bahan Baku}

Bahan baku yang digunakan adalah bunga melati kuncup atau kuntum yang diperoleh dari perkebunan Laura Florist dan langsung di ekstraksi dalam keadaan bunga masih segar.

\section{Ekstraksi Minyak Melati}

Bunga melati yang telah diperkecil ukurannya sebanyak 75 gram direndam dengan menggunakan pelarut n-heksana dengan perbandingan berat bunga melati (gram) dan volume pelarut $\mathrm{n}$-heksana $(\mathrm{ml})$ sebesar 1:3; 1:4; dan 1:5 didalam labu leher tiga. Labu leher tiga dipanaskan dengan suhu ekstraksi $30^{\circ} \mathrm{C} ; 35^{\circ} \mathrm{C}$, dan $40^{\circ} \mathrm{C}$ dan waktu ekstraksi 2 jam, 3 jam, 4 jam, dan 5 jam. Setelah proses ekstraksi selesai, campuran kemudian disaring dengan menggunakan kertas saring dan diperoleh campuran konsentrat minyak melati dan pelarutnya, setelah itu campuran tersebut dimurnikan.

\section{Pemurnian Minyak Melati}

Filtrat kemudian diambil untuk dievaporasi dengan vacuum rotary evaporator pada suhu $40^{\circ} \mathrm{C}$ selama 35 menit. Setelah konsentrat minyak atsiri terpisah dengan pelarutnya, dilakukan pencampuran dengan etanol dengan rasio konsentrat minyak atsiri bunga melati:etanol sebesar 1:10 (v/v) selama 20 menit, lalu kemudian dilakukan penyaringan dengan menggunakan kertas saring, untuk menghilangkan kandungan lilinnya. Campuran kemudian didinginan pada suhu $-5^{\circ} \mathrm{C}$ selama 24 jam, agar lilin yang masih tersisa kemudian mengendap. Setelah didinginkan, campuran kemudian disaring kembali dengan menggunakan kertas saring. Setelah dilakukan penyaringan, filtrat kemudian dievaporasi pada suhu $40^{\circ} \mathrm{C}$ dengan menggunakan vacuum rotary evaporator untuk memisahkan etanol sehingga dihasilkan minyak atsiri absolut.

\section{Analisa Komposisi dan Kualitas Minyak Atsiri Bunga Melati}

Produk yang dihasilkan akan dianalisis komposisinya dengan menggunakan GC-MS, dan dianalisis kualitasnya dengan metode SNI 06-2386-2006 yang meliputi uji warna, analisis indek bias, analisis bilangan asam, dan analisis bilangan ester.

\section{HASIL DAN PEMBAHASAN}

Pengaruh Suhu dan Waktu Ekstraksi terhadap Rendemen Absolut Minyak Atsiri Bunga Melati

Pengaruh suhu dan waktu ekstraksi terhadap rendemen absolut minyak atsiri bunga melati dengan menggunakan pelarut n-heksana dengan perbandingan massa bunga melati terhadap volume pelarut $(\mathrm{m} / \mathrm{v})$ 1:4 ditunjukkan pada Gambar 1.

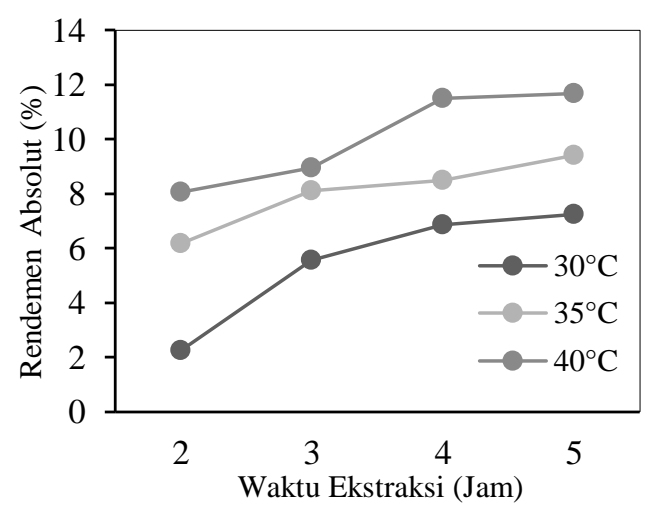

Gambar 1. Pengaruh Suhu dan Waktu Ekstraksi terhadap Rendemen Absolut Minyak Atsiri Bunga Melati pada suhu $30^{\circ} \mathrm{C} ; 35^{\circ} \mathrm{C}$; dan $40^{\circ} \mathrm{C}$ Selama 2 Jam, 3 Jam, 4 Jam, dan 5 Jam

Dari Gambar 1 dapat dilihat bahwa semakin lama waktu ekstraksi maka rendemen absolut minyak atsiri bunga melati yang diperoleh semakin meningkat. Dari keseluruhan data, dapat dilihat bahwa ekstraksi minyak atsiri bunga melati yang dilakukan selama 5 jam memiliki rendemen absolut yang lebih besar jika dibandingkan dengan ekstraksi yang dilakukan selama kurang dari 5 jam. Hal ini disebabkan karena semakin lama proses ekstraksi, maka kontak antara solvent dengan solute akan semakin lama sehingga proses pelarutan solute 
oleh solvent akan terus terjadi sampai solvent jenuh dengan solute [6]. Selain itu, dapat pula dilihat bahwa semakin tinggi suhu ekstraksi maka semakin tinggi pula rendemen absolut minyak atsiri bunga melati. Dari keseluruhan data, dapat dilihat bahwa ekstraksi minyak atsiri bunga melati yang dilakukan pada suhu $40^{\circ} \mathrm{C}$ memiliki rendemen absolut yang lebih besar jika dibandingkan dengan ekstraksi yang dilakukan pada suhu $30^{\circ} \mathrm{C}$ maupun $35^{\circ} \mathrm{C}$. Hal ini disebabkan penggunaan suhu tinggi untuk melakukan ekstraksi meningkatkan kelarutan dari solute. Suhu tinggi mampu melepaskan senyawa solute yang terikat, hal ini disebabkan oleh rusaknya unsur-unsur sel, menyebabkan semakin banyak senyawa yang dapat terekstrak [13]. Oleh karena itu, maka semakin meningkatnya suhu dan waktu ekstraksi, maka akan dihasilkan rendemen absolut minyak atsiri bunga melati yang meningkat pula.

\section{Pengaruh Rasio Massa Bunga Melati dengan Volume Pelarut terhadap Rendemen Absolut Minyak Atsiri Bunga Melati}

Pengaruh rasio massa bunga melati dengan volume pelarut $\mathrm{n}$-heksana terhadap rendemen absolut minyak atsiri bunga melati pada suhu $40^{\circ} \mathrm{C}$ selama 5 jam ditunjukkan pada Gambar 2.

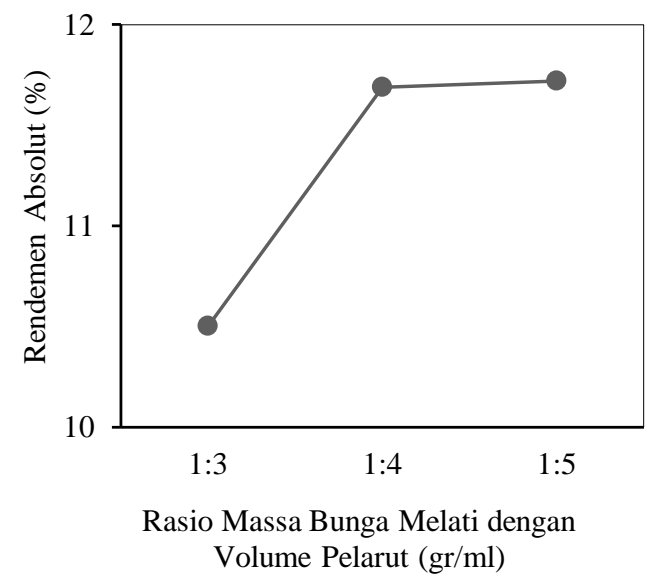

Gambar 2. Pengaruh Rasio Massa Bunga Melati dengan Volume Pelarut terhadap Rendemen Absolut Minyak Atsiri Bunga Melati pada Perbandingan 1:3; 1:4; dan 1:5

Dari Gambar 2 diatas dapat dilihat bahwa semakin besar perbandingan rasio massa bunga melati terhadap volume pelarut, maka rendemen absolut minyak atsiri bunga melati yang diperoleh semakin meningkat. Namun, pada rasio $1: 5$, besarnya rendemen yang didapat tidak terlalu signifikan jika dibandingkan dengan penggunaan rasio 1:4, sehingga menyebabkan kurang efisiennya proses ekstraksi jika menggunakan rasio 1:5 jika dilihat dari segi ekonomi. Hal ini disebabkan solvent sudah mencapai titik jenuhnya dimana semua minyak melati sudah terekstraksi. Hal ini disebabkan semakin besarnya rasio pelarut terhadap bunga, maka perbedaan konsentrasi antara pelarut dengan komponen yang terkandung didalam bunga akan semakin tinggi. Dengan demikian rendemen ekstraksi akan semakin meningkat. Meratanya distribusi pelarut ke padatan akan memperbesar rendemen minyak atsiri yang dihasilkan [6]. Oleh karena itu, maka semakin meningkatnya rasio massa bunga melati terhadap volume pelarut n-heksana, maka akan dihasilkan rendemen absolut minyak atsiri bunga melati yang meningkat pula.

\section{Analisis Komposisi Minyak Atsiri Bunga Melati dengan Menggunakan Gas Chromatography - Mass Spectrometer)}

Analisis GC-MS (Gas ChromatographyMass Spectrometer) terhadap minyak atsiri bunga melati yang dihasilkan melalui metode pelarut menguap ini bertujuan untuk mengidentifikasi komposisi senyawa-senyawa yang terkandung didalam minyak atsiri bunga melati. Analisis ini dilakukan pada minyak atsiri bunga melati yang memiliki rendemen absolut terbesar, yaitu minyak atsiri yang dihasilkan pada suhu ekstraksi $40^{\circ} \mathrm{C}$ selama 5 jam dengan perbandingan massa bunga melati terhadap volume pelarut n-heksana 1:4. Dari analisis komposisi menggunakan GC-MS diperoleh hasil dimana terdapat 19 komponen senyawa. Komponen yang memiliki persentase area terbesar pada minyak atsiri melati dapat dilihat dalam Tabel 1.

Tabel 1. Komponen yang Memiliki Persen Area Terbesar pada Minyak Atsiri Bunga Melati

\begin{tabular}{|c|c|}
\hline Komponen & Kadar (\%) \\
\hline Benzil Asetat & 47,14 \\
\hline $\begin{array}{c}\text { Alpha } \\
\text { Heksilsinnamic } \\
\text { Aldehid }\end{array}$ & 32,06 \\
\hline $\begin{array}{c}\text { 3-Sikloheksena-1- } \\
\text { metanol }\end{array}$ & 4,10 \\
\hline Terpineol & 2,83 \\
\hline Linalool & 2,63 \\
\hline
\end{tabular}

Kandungan komponen terbesar dari minyak melati hasil penelitian ini antara lain benzyl acetate sebesar $47,14 \%$ dan linalool sebesar 2,63\%. Menurut Sulong, komponen yang terdapat pada minyak atsiri bunga melati adalah benzyl acetate, linalool, benzyl alcohol, indole, benzyl benzoate, cis-jasmone, $\alpha$-hexylcinnamic aldehid, benzoic acids, benzaldehyde, y- 
terpineol, propanol, dan cis-3-hexenyl benzoate [8]. Hasil dari penelitian Hidayat, dkk. menghasilkan minyak atsiri bunga melati yang memiliki 38 komponen dengan kandungan komponen terbesarnya yaitu benzil asetat sebesar $15,78 \%$, linalil asetat sebesar $10,23 \%$, Cis jasmone sebesar $10,04 \%$. Hal ini disebabkan karena perbedaan kondisi operasi serta karakteristik bunga yang berbeda. Jasminum sambac yang digunakan dalam penelitian Hidayat berasal dari pulau Jawa, dengan kondisi geografis, cuaca, dan kondisi tumbuh yang berbeda dengan Jasminum sambac yang dibudidayakan di Sumatera, sehingga persentase senyawa yang dihasilkan juga berbeda.misalnya daerah budidaya bunga melati dan iklim dapat mempengaruhi karakteristik dari bunga melati [9].

\section{Analisis Kualitas Minyak Atsiri Bunga Melati dengan Parameter SNI}

Pengujian warna, indeks bias, bilangan asam, dan bilangan ester pada sampel minyak atsiri bunga melati dilakukan dengan menggunakan metode SNI 06-2385-2006. Hasil pada penelitian ini sesuai dengan hasil penelitian yang diperoleh oleh Nurjanah, dkk. yang melakukan penelitian mengenai ekstraksi minyak atsiri bunga melati dengan metode enfleurasi dan Hidayat, dkk. yang melakukan penelitian ekstraksi minyak melati (Jasminum sambac) dengan kajian jenis pelarut dan lama ekstraksi dengan menggunakan pelarut nheksana $[9,15]$. Hasil yang didapat ditunjukkan pada tabel 2 .

Tabel 2. Hasil Uji SNI 06-2385-2006

\begin{tabular}{|l|l|l|l|}
\hline $\begin{array}{c}\text { Parame- } \\
\text { ter }\end{array}$ & \multicolumn{1}{|c|}{$\begin{array}{c}\text { Hasil } \\
\text { Penelitian }\end{array}$} & Rujukan & Sumber \\
\hline Warna & Kuning & Kuning & {$[15]$} \\
\hline $\begin{array}{l}\text { Indeks } \\
\text { bias }\end{array}$ & 1,478 & $\begin{array}{l}1,470- \\
1,492\end{array}$ & {$[9]$} \\
\hline $\begin{array}{l}\text { Bilangan } \\
\text { asam }\end{array}$ & 20,92 & $\begin{array}{l}18,83- \\
29,85\end{array}$ & {$[15]$} \\
\hline $\begin{array}{l}\text { Bilangan } \\
\text { ester }\end{array}$ & 150,27 & $\begin{array}{l}143,408- \\
186,559\end{array}$ & {$[15]$} \\
\hline
\end{tabular}

\section{KESIMPULAN}

n-Heksana mampu melarutkan minyak atsiri yang terdapat pada bunga melati dengan kondisi ekstraksi terbaik berlangsung pada suhu $40^{\circ} \mathrm{C}$, waktu 5 jam, dan dengan rasio massa bunga melati dengan volume pelarut 1:4 dengan rendemen absolut sebesar 11,69\%. Minyak atsiri bunga melati yang dihasilkan mengandung benzil asetat sebesar $47,14 \%$ dan linalool sebesar $2,63 \%$, berwarna kuning, memiliki indeks bias sebesar 1,478, bilangan asam sebesar 20,92 mg
$\mathrm{KOH} / \mathrm{g}$ minyak atsiri, dan memiliki bilangan ester sebesar 150,27 mg KOH/ g minyak atsiri yang diuji menggunakan metode SNI 06-23852006 .

\section{DAFTAR PUSTAKA}

[1] A. Arce, A. Marchiaro, O. Rodriguez, dan A. Soto, Liquid-liquid equilibrium of diisoprophyl eter + ethanol + water system at different temperatures, Journal Chemical Engineering Data, 47, (2012) 529-532.

[2] A. E. Ramadhan dan H. A. Phaza, Skripsi, Fakultas Teknik, Universitas Diponegoro, Semarang, 2005.

[3] BiOrigins, Material Specifications Jasmine Absolute, Sandlehealth Industrial Estate, www.madarcorporation.co.uk, 2013, diakses pada Agustus 2018.

[4] Elwina, Irwan, dan U. Habibah, Proses ekstraksi minyak bunga melati (Jasminum sambac) dengan metode enfleurasi, Jurnal Reaksi (Journal of Science and Technology), 4, (2006).

[5] H. Nisak, Wignyanto, dan N. L. Rahmah, Ekstraksi melati putih menggunakan teknologi kejut listrik terhadap mutu minyak atsiri concrete (kajian rasio bahan baku, pelarut heksana, dan lama kejutan listrik), Jurnal Industria, 3, (2014) 43-52.

[6] K. Jeremia, S. Zain, S. Nurjanah, A. Widyasanti, dan S. H. Putri, Pengaruh lama ekstraksi terhadap rendemen dan mutu minyak melati menggunakan metode ekstraksi pelarut menguap (solvent extraction), Jurnal Teknotan, 10, (2016) 34-43.

[7] L. Gustina, Market Brief 2014, Minyak Atsiri ATDAG KBRI Berlin, Kementrian Perdagangan Republik Indonesia, Indonesia, 2014.

[8] M. F. Sulong, Tesis, University College of Engineering \& Technology, Malaysia, 2006.

[9] N. Hidayat, I. A. Dewi, dan D. A. Hardani, Ekstraksi minyak melati (jasminum sambac) (kajian jenis pelarut dan lama ekstraksi), Jurnal Industria, 4, (2016) 82-88.

[10] N. O. Benedicta, S. Zain, S. Nurjanah, A. Widyasanti, dan S. H. Putri, Pengaruh rasio bunga dengan pelarut terhadap rendemen dan mutu minyak melati menggunakan metode ekstraksi pelarut menguap (solvent extraction), Jurnal Teknotan, 10, (2016) 44-50. 
[11] N. S. Sani, R. Racchmawati, dan Mahfud, Pengambilan minyak atsiri dari melati dengan metode enfleurasi dan ekstraksi pelarut menguap, Jurnal Teknik PomITS, 1, (2012) 1-4.

[12] Sisco Research Laboratories, Material Safety Data Sheet Diisopropyl Eter Extrapure, www.srlchem.com, 2013, diakses pada Agustus 2018.

[13] Sridianti, Pengertian Heksana dan Penggunaan Heksana. www.sridianti.com, 2014, diakses pada Agustus 2018.

[14] Sukardi, A. P. Pinasthika, M. H. Pulungan, A. F. Mulyadi, Ekstraksi minyak atsiri bunga melati, (2016).

[15] S. Nurjanah, I. Sulistiani, A. Widyasanti, dan S. Zain, Kajian ekstraksi minyak atsiri bunga melati dengan metode enfreurasi, (2016) 13-20.

[16] S. P. Suyanti dan Sjaifullah, Buletin Plasma Nutfah, Jakarta, 2003, p. 19-22.

[17] Wikipedia, Pelarut Non-polar N-heksana. www.wikipedia.com, 2018, diakses pada Agustus 2018. 